\title{
US EXECUTIVE BRANCH PATENT POLICY, GLOBAL AND DOMESTIC
}

Arti K. Rai*

\section{Introduction}

Over the last few decades, the US executive branch has been a central player in numerous struggles over the content of global parent law. Although the venue for these struggles has frequently shifted, the executive branch has consistently favored strong patent rights. In this chapter, I discuss how US global positioning compares to positions taken by executive branch agencies that focus on domestic policy. I also discuss how the rise of China may affect not only US global and domestic patent policy but also larger questions of "innovation policy."

\section{A Brief History of US Efforts}

Starting in the 1980s, the US and like-minded countries engineered a transfer of patent law discussions from the World Intellectual Property Organization (WIPO) to a venue, the World Trade Organization (WTO), that they viewed as more friendly to strong patent rights. At the WTO, these countries succeeded in promulgating a suite of minimum intellectual property standards in the 1994 Agreement on Trade-Related Aspects of Intellectual Property Rights (TRIPS Agreement).

- Elvin R. Latty Professor, Duke Law School. From 2009 to 2010, I served as the Administrator for Policy and External Affairs at the US Patent and Trademark Office (USPTO). This contribution relies only on publicly available information, however. I thank Larry Helfer and Ruth Okediji for helpful comments. Richard Lee provided exceptional research assistance.

1. See Susan K. Sell, Private Power, Public Law: The Globalization of Intellectual Property Rights (2003); Jerome H. Reichman. Universal 
Subsequently, when Geneva-based institutions not only proved resistant to further increases in global patent protection, ${ }^{2}$ but actually emerged as fora for pushing back on the TRIPS Agreement, ${ }^{3}$ the United States shifted its efforts to bilateral and plurilateral agreements. The United States currently has "TRIPS-plus" intellectual property provisions in bilateral treaties negotiated with numerous developing countries, including Bahrain, Cambodia, Chile, Colombia, Costa Rica, Jordan, Nicaragua, Oman, Panama, Peru, and Vietnam. ${ }^{4}$

On the plurilateral patent front, the United States has also been active, if less immediately successful. Although some scholars had argued that the Anti-Counterfeiting Trade Agreement (ACTA) could inhibit access to generic drugs by encouraging parties to adopt border measures to interdict drugs suspected of patent or trademark infringement, ${ }^{5}$ the treaty's border measures ultimately excluded patents. ${ }^{6}$ Activity now centers on the Trans-Pacific Partnership Agreement (TPP), a plurilateral agreement being negotiated among the United States, Australia, New Zealand, Chile, Brunei, Singapore, Peru, Viernam, Malaysia, and (most recently) Japan.

The patent provisions of these bilateral and plurilateral agreements focus on pharmaceuticals. 'The provisions of the draft TPP agreement appear representative. Although an official draft of the TPP has not been made public, leaked drafts include a host of requirements related to pharmaceuticals. ${ }^{8}$ Perhaps the most significant is a requirement that signatories allow so-called "secondary" patents. These are

Minimum Standards of Intellectual Property Protection under the TRIPS Component of the WTO Agreement, 29 INT'L LaWYER 345 (1995).

2. Rochelle Dreyfuss \& Jerome H. Reichman, Harmonization without Consensus: Critical Reflection on Drafting a Substantive Patent Law Treaty, 57 DUKE L.J. 86 (2007).

3. Laurence R. Helfer, Regime Shifting: The TRIPS Agreement and the New Dynamics of International Intellectual Property Making, 29 YALE J. INT'L L. 1 (2004).

4. Susan K. Sell, TRIPS Was Never Enough: Vertical Forum Shifting, FTAs, ACTA, and TPP, 18 J. INTELl. Prop. L. 447 (2011).

5. Cynchia Ho, Global Access to Medicine: The Influence of Competing Patent Perspectives, 34 Fordham INT'L L.J. 1 (2011); Henning Grosse Ruse-Khan, A Trade Agreement Creating Barriers to International Trade? ACTA Border Measures and Goods in Transit, 26 AM. U. INT'L L. REv. 645 (2011).

6. In any event, the decision by the European Parliament to reject ACTA renders these concerns less pressing. See Press Release, European Parliament, European Parliament Rejects ACTA (July 4, 2012), available at hrtp://www.europarl.europa.eu/news/en/pressroom/ content/20120703IPR48247/heml/European-Parliament-rejects-ACTA.

7. See, e.g., Dominican Republic-Central America-United States Free Trade Agreement (CAFTA-DR), arts. 15.9-15.10, Aug. 5, 2004; United States-Oman Free Trade Agreement, arts. 15.8-15.9, Jan. 19, 2006.

8. See Trans-Pacific Partnership (TPP), Intellectual Property Chapter, Draft-Feb. 10, 2011 , available at http://keionline.org/sites/default/files/tpp-10feb2011-us-text-ipr-chapter.pdf 
patents that cover not the drug's primary active chemical compound but, instead, modified forms of the compound (e.g., salts, isomers), new uses of the compound, or new methods of using the compound.' According to one leaked draft, the TPP's secondary patent provision states that patents on new forms, uses, and methods "may satisfy the criteria for patentability, even if such invention does not result in the enhancement of the known efficacy of that product." ${ }^{\text {"10 }}$ This provision appears to be a direct response to Article 3(d) of the Indian Patent Act, which prohibits granting patents on "the mere discovery of a new form of a known substance which does not result in the enhancement of the known efficacy of that substance...."11

Other significant TPP provisions include a mandate of data exclusivity to the originator firm that supplies the clinical data for the national regulatory authority's approval of a drug. The draft agreement calls for five years of exclusivity from the date of marketing approval of a new "pharmaceutical product" ${ }^{\text {"12 }}$ and three years from the date of marketing approval based on new "clinical information." ${ }^{13}$ The TPP draft also calls for legal linkage between patents and approval by a regulatory authority of generic marketing. Specifically, prior to securing approval, the generic firm must show that patents relevant to the drug have expired, are invalid, or are not infringed. ${ }^{14}$ This legal linkage has the potential to delay generic marketing, as does a TPP provision calling for patent term extension based on regulatory delays. ${ }^{15}$ Finally, TPP signatories are supposed to agree to limits on pre-grant opposition proceedings and to border measure provisions to interdict goods suspected of patent infringement, including in-transit goods. ${ }^{16}$

[hereinafter TPP1]; Trans-Pacific Partnership (TPP), Intellectual Property Chapter (Selected Provisions), Draft-Sept. 2011, available at http://www.citizenstrade.org/ctc/wp-content/ uploads/2011/10/TransPacificIP1.pdf [hereinafter TPP2].

9. See generally Michael Burdon \& Kristie Sloper, The Art of Using Secondary Patents to Improve Protection, 3 Int'L J. Med. MARketing 226 (2003); European Commission, Pharmaceutical Sector Inquiry: Final Report 184-92 (2009), available at http://ec.europa.eu/competition/ sectors/pharmaceuticals/inquiry/staff_working_paper_part1.pdf.

10. TPP1, supra note 8 , art. 8 .

11. The Patents (Amendment) Act, No. 15 of $2005, \$ 3$ (d) (Universal 2005).

12. TPP2, supra note 8 , art. $9.2(\mathrm{a})$.

13.Id. art. 9.2 (c).

14. Id. art. 9.5 .

15.Id. art. 8.6(b).

16. TPP1, supra note 8 , arts. 8.7, 14.4; see also Medecins Sans Frontieres, Trading Awary Health: How the U.S.'s Intellectual Property Demands for the Trans-Pacific Partnership Agreement Threaten Access to Medicines, Aug. 2012, available at http://aids2012.msf.org/wp-content/ uploads/2012/07/TPP-Issue-Brief-IAC-July2012.pdf. 


\section{Comparing International and Domestic Positions}

To a significant extent, the pharmaceutical patent positions being advocated by the United States internationally overlap with current US law. As discussed further below, US law allows at least certain types of secondary patents. United States' law also confers five- and three-year data exclusivity terms for originator applications, establishes a linkage between patenting and approval of generics by the Food and Drug Administration (FDA), contains patent term extensions for delays in both patent processing at the US Patent and Trademark Office (USPTO) and regulatory approval delays at the FDA, and prohibits pre-grant opposition.

The extent to which the US-style approach to pharmaceutical patents is appropriate for poorer countries is the subject of tremendous dispute. Presumably, however, US executive branch advocacy for patent rights abroad stronger than those for which it advocates domestically would be even more controversial. Thus it is worth examining whether the US international posture is in fact more "pro-patent" than its domestic posture.

One candidate for such inconsistency is the US non-obviousness requirement. As compared with its application in others areas of technology, judicial application of the non-obviousness requirement in pharmaceuticals has been relatively robust. ${ }^{17}$ Notably, the executive branch has consistently supported a strong non-obviousness requirement. In fact, in 2007 , the executive branch was influential in persuading the US Supreme Court to issue an opinion, KSR v. Teleflex, ${ }^{18}$ making it clear to lower courts that non-obviousness was an important gatekeeper requirement for all patent applications. ${ }^{19}$

The executive branch's domestic support for non-obviousness as a muscular requirement is arguably in tension with its international position that secondary patents on new formulations "may satisfy the criteria for patentability, even if such invention does not result in the enhancement of the known efficacy of that product. ${ }^{20}$ Although US non-obviousness law does not deny secondary formulation patents, it typically subjects them to a requirement that the formulation have unexpected properties. ${ }^{21}$ Moreover, during the Obama administration, the executive branch brought a Supreme Court case arguing that US antitrust law, US patent law, and the US "Hatch-Waxman" regime for patent linkage and generic

17. Arti Rai, Building a Better Innovation System: Combining Facially Neutral Patent Standards with Regulation of End Product Therapeutics, 45 Hous. L. Rev. 1037 (2008).

18. 550 U.S. 398 (2007).

19. Arti Rai, Who's Afraid of the Federal Circuit?, 121 YALE L.J. ONL. 135 (2011).

20. TPP1, supra note 8 , art. 8 .

21. Rai, supra note 17. 
entry are all intended to encourage validity challenges by generics to secondary pharmaceutical patents that might be non-obvious or otherwise invalid."2 Over the strong objections of the branded pharmaceutical industry, the Obama administration also successfully argued in favor of allowing generic entry in cases where the generic states it will not market its product for uses indicated in secondary method-of-use patents. ${ }^{23}$

Ultimately, in part because of execurive branch advocacy of robust generic entry through Hatch-Waxman, the actual time to generic entry has remained stable over the past decade despite increases in secondary patenting. ${ }^{24}$ In contrast, no suggestion that signatories are permitted to constrain secondary patenting through robust generic challenge appears in the language of the leaked TPP drafts. Thus, there is arguably some tension in the US executive branch's domestic and international positions.

A realist who assumes that states pursue only their immediate material interest (with more or less success depending on their military and economic clout) ${ }^{25}$ would presumably find little reason for congruence between domestic and international positions. Even so, delving into the institutional dynamics that lead to divergent domestic and international positions highlights the agendas, and relative power, of different agencies.

Consider first the domestic context. Although certain agencies and White House offices may be quite supportive of strong domestic patent rights, they compete for influence on questions of domestic patent policy with agencies typically more wary of patent rights. The latter group includes the Antitrust Division of the Department of Justice (DOJ), the Federal Trade Commission (FTC), and the Department of Health and Human Services (HHS). ${ }^{26}$ On the specific question of pharmaceutical patent policy, DOJ Antitrust, FTC, and HHS have all committed themselves quite publicly to facilitating domestic generic entry so as to achieve low-cost access for US patients. ${ }^{27}$ Although the commitment of the

22. Brief for the Petitioner, FTC v. Actavis, Inc., 133 S. Ct. 2223 (2013) (No. 12-416), available at http://www.justice.gov/atr/cases/f291700/291720.pdf.

23. Arti Rai, Use Patents, Carve-Outs, and Incentives-A New Battle in the Drug Patent Wars, 367 N. ENGL. J. MED. 491 (2012).

24. Scott C. Hemphill \& Bhaven N. Sampat, Evergreening, Patent Challenges, and Effective Market Life in Pharmaceuticals, 31 J. Health Econ. 327 (2012).

25. Anne-Marie Slaughter, International Relations, Principal Theories, in MAX PLANCK ENCyClopedia of Public International Law (R. Wolfrum ed., 2011).

26. Rai, supra note 23.

27. See, e.g., Fed. Trade Comm'n (FTC) \& Dep't of Justice (DOJ), Improving Health Care: A Dose of Competition (2004), available at http://www.ftc.gov/ reports/healthcare/040723healthcarerpt.pdf. 
DOJ Antitrust and the FTC is largely ideological, agencies such as HHS, as well as powerful White House offices such as the Office of Management and Budget, have a direct budgetary interest in costs incurred by public insurance programs.

By contrast, although an executive branch constituency for low-cost global access does exist, its strength is limited. Domestically oriented agencies obviously do not have a strong financial stake in global access. To the extent they support such a goal in principle, they are likely to manifest such support through laudable but modest programs that emphasize voluntary incentives for patent holders. During the first Obama administration, for example, the USPTO established a program under which entities that demonstrate successful deployment of technology for humanitarian use can receive accelerated patent processing. ${ }^{28}$

International humanitarian programs, such as the President's Emergency Plan for AIDS Relief (PEPFAR), which provides antiretroviral (ARV) drugs to 5.1 million of the 8 million individuals currently receiving ARVs in low- and middle-income countries, do have a direct financial stake in low-cost global access. Congress scrutinizes the activities of PEPFAR (and the Department of State office that manages PEPFAR) to determine whether it is procuring ARV drugs at a low per-patient cost, ${ }^{29}$ To fulfill this goal, PEPFAR relies heavily on generic drug producers such as India. Indeed, according to a recent Government Accountability Office (GAO) report, from 2005 to 2011, PEPFAR's reliance on generic ARVs increased from 15 percent by volume to 98 percent. ${ }^{30}$ This increase saved PEPFAR approximately $\$ 934$ million, allowing the program to expand coverage rapidly and to include World Health Organization-recommended products, such as fixed-dose combination products that do not have an equivalent branded formulation. ${ }^{31}$

Particularly in times of national economic stress, however, the power of these constituencies is not comparable to that of economically oriented offices such as the Office of the United States Trade Representative (USTR). Although USTR is a small office with a budget of less than $\$ 100$ million, its career staff is highly skilled, it is committed to strong global IP rights, and it has close connections

28. Quentin Palfrey \& Hillary Chen, Retwarding Inventors Who Work to Solve Global Challenges, WhiteHouse.Gov (Feb. 8, 2012 10:22 AM), http://www.whitehouse.gov/ blog/2012/02/08/rewarding-inventors-who-work-solve-global-challenges (discussing the launch of the Patents for Humanity program).

29. U.S. Gov't Accountability Office, GaO-13-345, President's Emergency PLAN FOR AIDS RELIEF (2013), available at http://www.gao.gov/products/GAO-13-345.

30. Id.

31. Id. 
with US corporate leadership. The USTR thus exercises significant influence across changes in political leadership.

From a realist perspective, the ability of other countries to challenge the United States is also limited. Although certain large emerging economies such as India might invoke the manner in which US domestic law diverges from TPP as rhetorical support for their own efforts to develop alternatives to TPP-type regimes, ${ }^{32}$ mere compelling rhetoric is unlikely to diminish US infuence, particularly in the bilateral and plurilateral context.

Even perspectives that emphasize the role of multilateral institutions in mediating longer-term, iterated bargaining between states might deem the US approach a relatively stable equilibrium. On this view, deviations between the positions the United States is advocating internationally and domestically are sufficiently narrow that they may fail to impress even international institutions that have a "pro-access" agenda. Moreover, from the standpoint of delivering a clear public message, both these institutions and civil society groups may prefer to emphasize not narrow technical differences between US global and domestic approaches but instead what they see as direct links between the strong patenting and lack of access.

Going forward, the situation may change if the US healthcare spending dilemma becomes sufficiently untenable that more dramatic moves are made with respect to biopharmaceutical patents. But for the moment the United States is likely to be able to manage any tensions in its global and domestic positions.

I turn next to the potentially disruptive role of China. Because China's development strategy has generally been "pro-patent," and because it has specifically refrained from playing a leadership role in global controversies over access to medicines, China's rise probably will not disrupt the equilibrium that the United States has achieved on biopharmaceutical patents. Nonetheless, as discussed below, China is likely to play a role in numerous domestic deliberations outside the biopharmaceutical arena. On the global stage, China's relationship to the American-led TPP negotiations will be an issue worth watching.

\section{The Rise of China}

For several reasons, China's rise is qualitatively different from what has come before, at least since the rise of the Japanese economy in the 1970s and 1980s. Most obviously, unlike other nations, China represents a serious threat to US global economic dominance. Additionally, in contrast to large emerging

32. Amy Kapczynski, Harmonization and Its Discontents: A Case Study of TRIPS Implementation in India's Pharmaceutical Sector, 97 CAL. L. REv. 1571 (2009). 
economies such as India and Brazil, which have generally favored weaker patent protection, China has become substantially more aggressive than the United States in encouraging its firms to seek patents.

That said, the Chinese approach toward patents has not been unilaterally "pro-patent." To the contrary, in the context of standard setting and patents, China has sometimes taken positions that could be seen as "anti-patent," perhaps on the theory that standard setting represents a context where aggressive patent assertions have the potential to create particularly acute "holdup" problems for follow-on innovation. ${ }^{33}$ Relatedly, China appears to view patents as an integral piece of a broader innovation policy. Indeed, since 2006, China has been implementing a sweeping "innovation strategy" in which patents represent one lever. By contrast, the US executive branch has historically resisted discussions of innovation policy, lest such discussions be seen as veering too close to an endorsement of industrial policy.

How the unique case of China's patent and innovation policy affects US positions domestically and internationally is a story that is only beginning to unfold. After discussing China's patent and innovation policy, I offer some preliminary thoughts.

\section{China's Patent and Innovation Policy}

In 2011, the Chinese State Intellectual Property Office (SIPO) promulgated a National Patent Development Strategy in which it set forth a goal of two million patent applications by 2015. By way of comparison, the USPTO had 25 percent of that figure (540,000 applications) in 2012. To be sure, the two million figure misses important distinctions between invention patents that have been examined for inventiveness and appropriate scope by an administrative agency (so-called invention patents) and utility models available without examination. The figure also fails to distinguish between domestic invention patents and invention patents filed by firms based in other countries.

However, even if we focus only on domestic invention patents, China's trajectory is notable. Since 2000, most of the growth in China's domestic patent applications has come from domestic invention patents. ${ }^{34}$ As a consequence, although foreign and domestic inventors filed approximately similar numbers of invention patents until 2005, by 2008 the domestic inventor percentage of applications

33. Mark Lemley \& Carl Shapiro, Patent Holdup and Royalty Stacking, 85 Tex. L. Rev. 1991 (2007).

34. Albert Hu \& Gary Jefferson, A Great Wall of Patents: What Is Behind China's Recent Patent Explosion?, 90 J. Dev. Econ. 57 (2009). 
filed had increased to 67.1 percent. Additionally, by 2008 , the absolute number of domestic invention patent grants was equal to foreign invention patent grants. By 2011, SIPO was ahead of the USPTO with respect to domestic invention patent applications filings and grants in the respective offices. SIPO had 415,829 domestic invention patent applications, as compared with 247,750 for the USPTO, and 112,347 domestic invention grants, as compared with 108,626 for the USPTO. ${ }^{35}$

Another traditional proxy for patents that are likely to have commercial value is patents filed at WIPO via the Patent Cooperation Treaty (PCT). China's numbers here are also rising rapidly. In 2011, China occupied the fourth spot, behind the United States, Japan, and Germany. ${ }^{36}$

In part, these increasing numbers reflect a deliberate strategy by the Chinese government to encourage patenting. According to the US International Trade Commission (USITC), provincial governments offer payments to Chinese companies to support the filing of patents in China and overseas. ${ }^{37}$ Chinese companies may also qualify for tax relief, research awards, and government contracts through patenting ${ }^{38}$ In some cases, China is giving specific funds to small and medium-sized firms that file abroad. For example, in October 2009, the Chinese Ministry of Finance announced a 100 million RMB fund to help small and medium enterprises (SMEs), as well as public research institutions, file abroad. ${ }^{39}$

That said, the firms most responsible for high levels of Chinese patenting both domestically and abroad are large information and communications technology (ICT) firms. ${ }^{40}$ Indeed, in 2011, two Chinese telecommunications firms, ZTE Corp. and Huawei Technologies, had the largest and third-largest number of PCT applications respectively. For these firms, the Chinese government may be interested not so much in innovation per se as in the need to assemble defensive patent portfolios in order to compete in the global ICT marketplace.

35. Peter Yu, Five Oft-Repeated Questions About China's Recent Rise as a Patent Power, 2013 Cardozo L. Rev. De Novo 78 (2013).

36. World Intellectual Prop. Org. (WipO), World Intellectual Property INDICATORs 63 (2012), available at http://www.wipo.int/export/sites/www/freepublications/en/intproperty/941/wipo_pub_941_2012.pdf.

37. U.S. Int'L Trade Comm'n (USITC), Pub. No. 4199, China: IP Infringement, Indigenous Innovation Policies and Framework for Measuring the Effects on the U.S. Economy (2010), available at http://www.usitc.gov/publications/332/pub4199.pdf.

38. Id.

39. Tu Lei, Ministry of Finance to Support Overseas Patents, AliBABA.COM (Oct. 13, 2009, 8:02 AM), http://news.alibaba.com/article/detail/business-in-china/100182805-1-mof-supportoverseas-patents.html.

40. Markus Eberhardt, Christian Helmers \& Zhihong Yu, Is the Dragon Learning to Fly? In Analysis of the Chinese Patent Explosion, (Univ. of Oxford Ctr. for the Study of African Econs. Working Paper Series, No. 2011-15, 2011). 
The Chinese government has not, however, been uniformly "pro-patent." To the contrary, in 2009, the government proposed regulations that would have required patented technology relevant to national standards to be subject to compulsory licensing either royalty-free or at below-market rates. ${ }^{41}$ Although the government then acceded to commentary by foreign firms strongly opposing these proposed regulations, it still manages standard setting centrally. ${ }^{42}$

China's patent strategy is just one part of an overall fifteen-year innovation strategy. The strategy, summarized in a 2006 document entitled the "National Medium and Long Term Plan for Science and Technology Development," not only specifies domestic invention patent goals (further refined in the 2011 patent plan noted earlier) but more broadly calls for China to become an "innovation-oriented society" by $2020 .{ }^{43}$ The approach suggested by the plan includes: an emphasis on "zuzhu chuangxin"-a somewhat ambiguous concept often translated as "indigenous innovation, ${ }^{\text {"4h }}$ prioritizing certain areas of frontier technology, the development of an "integrated national system of institutions supportive of R\&D", increased funding for R\&D, and assimilation of foreign technology.

\section{The US Reaction}

Thus far, the US executive branch has reacted most strongly, at least at the rhetorical level, to the Chinese "indigenous innovation" strategy. It has particularly objected to the government procurement preferences for Chinese firms, which form part of the strategy. These objections may form part of the basis for US resistance to Chinese participation in the TPP negotiations.

The executive branch's reaction to the notable growth in Chinese patent applications and patents has emphasized quality problems, particularly in utility applications that are not examined. For example, even the White House Office of the Intellectual Property Enforcement Coordinator, which traditionally advocates for strong intellectual property protection internationally, has publicly expressed concern about the quality of "unexamined utility model patents. ${ }^{\text {"45 }}$ Presumably

41. USITC, supra note 37.

42. Id. U.S. INT'L TRADE COMm'N (USITC), China: Effects of IP Infringement and Indigenous Innovation Policies on the U.S. Economy (2011) available at http://www.usitc. gov/publications/332/pub4226.pdf.

43. Cong Cao, Richard P. Surtmeier \& Denis F. Simon, China's 15-Year Science and Technology Plan, 59 Physics TODAy 38-43 (2006).

44. Yu, supra note 35.

45. Mark MacCarthy, China's Utility Model System: A Perfect Storm for Patent Trolls, DigrtaL Discourse (Sept.20, 2012), http://www.siia.net/blog/index.php/2012/09/chinas-utility-m odel-patent-system-a-perfect-storm-for-patent-trolls (last visited Sept. 5, 2013). 
these concerns are also being expressed in private bilateral meetings, and will become more acute as China's patent litigation docket continues to increase significantly and we see more cases of Chinese firms using patents arguably of dubious quality to sue US firms.

Agreement across the executive branch about poor Chinese patent quality could bolster efforts to improve patent quality domestically. Alternatively, the executive branch might feel compelled to compete with China on patent applications and grants. The domestic effect in the United States of Chinese efforts in the areas of standard setting and innovation policy could also be significant. In standard setting, the executive branch has, since 1998, had a formal policy of deferring to private sector efforts. Specifically, Office of Management and Budget (OMB) Circular A-119, entitled "Federal Participation in the Development and Use of Voluntary Consensus Standards and in Conformity Assessment Activities," directs agencies that need to adopt standards generally to defer to decisions made by private sector standard-setting bodies. ${ }^{46}$ This deferential policy has, however, been criticized for being outdated, particularly in light of increasing concerns about holdup when private standard-setting bodies have unclear policies on patents. Even so, the executive branch has not amended Circular A-119.

A recent statement by OMB, USTR, and the White House Office of Science and Technology Policy (OSTP) does indicate that, in certain areas of "national priority," such as health information technology and promoting clean energy, federal agencies might be more proactive with respect to standards. ${ }^{47}$ Overall, however, the document reaffirms a commitment to private-sector leadership in the area. A desire on the part of certain executive branch offices (and like-minded congressional leaders) to present a strong counter-example to China may constrain domestic action on standards. Similarly, the need to draw a stark contrast with China may represent at least a rhetorical obstacle to the adoption of highly proactive executive branch innovation policies.

Ultimately, concerns about drawing contrasts with China are probably less important than purely domestic factors such as pro-market ideology, political gridlock, or dramatic fiscal constraints. Even so, of any country that could affect US patent and innovation policy in the domestic context, China is the likeliest candidate.

46. Office of Mgmt. \& Budget, Exec. Office of the President, OMB Circular No. A-119, Federal. Participation in the Development and Use of Voluntary Consensus Standards and in Conformity Assessment Activities, 63 Fed. Reg. 8546 (Feb. 19, 1998), available at http://www.whitehouse.gov/omb/circulars_al19_al19fr.

47. Memorandum from the Office of Mgmt. \& Budget, U.S. Trane Rep. \& Office. OF SCIEnCe \& TeCh. Pol'y (Jan, 17, 2012), available at http://www.whitehouse.gov/sites/ default/files/omb/memoranda/2012/m-12-08.pdf. 
On the global patent stage, one key question to watch will be China's relationship to the TPP negotiations. With respect to the possibility of Chinese entry, US executive branch views will be influenced in part by wariness regarding the impact of Chinese patent and innovation policy on the interests of US firms. By the same token, any aggressive move by the United States to exclude China may have unintended consequences in terms of causing China to more aggressively pursue patent and innovation strategies that explicitly favor Chinese firms. 